\title{
Heparin Regulates Endothelin Production through Endothelium-derived Nitric Oxide in Human Endothelial Cells
}

Koji Yokokawa, *' Hideki Tahara, " Masakazu Kohno, * Anil K. Mandal," Masashi Yanagisawa," and Tadanao Takeda * ${ }^{*}$ First and ${ }^{\ddagger}$ Second Departments of Internal Medicine, Osaka City University Medical School, Osaka 545, Japan; ${ }^{5}$ Department of Medicine, Wright State University and Veterans Affairs Medical Center, Dayton, Ohio 45428; and "Howard Hughes Medical Institute and Department of Molecular Genetics, University of Texas Southwestern Medical Center at Dallas, Dallas, Texas 75235

\begin{abstract}
Heparin shows blood pressure lowering effect in hypertensive patients and animal models. The present study examined the effect of heparin on vasoconstrictor endothelin-1 (ET-1) production in cultured human umbilical vein endothelial cells (ECs) to elucidate the mechanism of antihypertensive effect of heparin. Heparin suppressed both basal and thrombin-stimulated ET-1 mRNA expression paralleled with a decrease in ET-1 peptide release in a dose-dependent manner. Heparin concomitantly enhanced nitric oxide (NO) formation measured by $\mathrm{NO}_{2} / \mathrm{NO}_{3}$ levels and cGMP production in ECs. These enhancements were more marked when ECs were stimulated by thrombin. However, these heparin's effects were blunted in the presence of endothelium-derived nitric oxide (EDNO) synthesizing inhibitor $\mathbf{N}^{\mathbf{G}}$-monomethyl $\mathbf{L}$-arginine. Therefore, these results suggest that suppression of ET-1 production by heparin is EDNO mediated. (J. Clin. Invest. 1993.92:2080-2085.) Key words: endothelin • heparin • endothelial cell • endothelium-derived nitric oxide $\bullet \mathbf{N}^{\mathbf{G}}$-monomethyl L-arginine
\end{abstract}

\section{Introduction}

Heparin, which is widely used as an anticoagulant, given chronically shows a blood pressure-lowering effect in hypertensive patients $(1,2)$ and animal models (3-5). This antihypertensive effect is accompanied by a profound fall in total peripheral resistance (6). However, the physiological role of circulating heparin remains in question.

Endothelin-1 (ET-1), ${ }^{1}$ identified (7) as a product of vascular endothelial cells (ECs), exerts potent vasoconstrictor and vascular smooth muscle cell (VSMC) proliferative actions (8). Elevated levels of this peptide have been reported in patients with acute myocardial infaction (9), acute renal failure (10), or severe hypertension $(11,12)$. On the other hand, endothe-

Address correspondence to Dr. Koji Yokokawa, First Department of Internal Medicine, Osaka City University Medical School, 1-5-7 Asahimachi, Abeno-ku, Osaka 545, Japan. 1993

Received for publication 4 March 1993 and in revised form 30 June

1. Abbreviations used in this paper: $\mathrm{AD}$, actinomycin-D; $\mathrm{EC}$, endothelial cell; ECGS, endothelial cell growth supplement; EDNO, endothelium-derived nitric oxide; ET-1, endothelin-1; LNMMA, $\mathrm{N}^{\mathrm{G}}$-monomethyl L-arginine; SHR, spontaneously hypertensive rats; VSMC, vascular smooth muscle cell.

J. Clin. Invest.

(c) The American Society for Clinical Investigation, Inc.

0021-9738/93/10/2080/06 \$2.00

Volume 92, October 1993, 2080-2085 lium-derived nitric oxide (EDNO), which is also released from vascular ECs, exerts vasodilator action in humans (13) and is thought to function as a modulator of VSMC mitogenesis and proliferation by a cGMP-mediated mechanism (14). Thrombin stimulates the production of both ET-1 and EDNO (15). EDNO released during stimulation with thrombin inhibits the production of ET-1 via a cGMP-dependent pathway in aortic ECs (15).

Recently, we have shown that bolus administration of ET-1 to heparin-treated (4 wk) spontaneously hypertensive rats (SHR) showed an exaggerated initial depressor response and a blunted pressor response compared to those in control SHR. In addition, heparin effectively suppressed ET-1 release from cultured rat ECs (16). These findings have led us to hypothesize that heparin's antihypertensive effect is EDNO mediated.

This study was designed to examine whether heparin affects ET-1 production in human ECs; and if this effect is influenced by EDNO inhibitor $\mathrm{N}^{\mathrm{G}}$-monomethyl $\mathrm{L}$-arginine (LNMMA), in order to further elucidate the heparin's antihypertensive mechanism. It is critical that we reevaluate the mechanism of action of heparin in human endothelial cells for its potential application in clinical use.

\section{Methods}

Cell culture. Human ECs were obtained from umbilical veins according to the method described previously (17). Cells were grown in medium-199 (Gibco BRL, Grand Island NY) supplemented with 5\% ( vol/vol) FCS, endothelial cell growth supplement (ECGS) at $50 \mathrm{mg} /$ $\mathrm{ml}$ (Sigma Chemical Co., St. Louis, MO.), penicillin $(50 \mu \mathrm{U} / \mathrm{ml})$, and streptomycin $(50 \mu \mathrm{g} / \mathrm{ml})$. EC purity was assessed by phase contrast microscopy involving a detection of a characteristic "cobblestone appearance" and by immunofluorescence staining with a Factor VIII antiserum. VSMC contamination was less than $0.1 \%$. The cultured ECs had three to five passages before being used in this study. When cells were confluent, the medium was replaced and incubated with fresh medium-199 without serum and ECGS for $24 \mathrm{~h}$ before the experiments. After removal of the culture medium, ECs were incubated with several agents, including heparin derived from bovine lung and having its Activity at 140 USP U/mg, and thrombin (both from Sigma Chemical Co.), and LNMMA (Calbiochem Corp., San Diego, CA.), or these agents in combination, in serum-free medium-199 without ECGS.

Extraction and RIA of ET-1. ET-1 was extracted from 4-ml-culture medium through a Sep-Pak C18 cartridge (Waters Chromatography Div., Millipore Corp., Milford, MA) by the method described previously (11). The ET-1 concentration in the medium was measured by radioimmunoassay with the use of antibody against ET-1 (Peninsula Lab. Inc., Belmont, CA) and ${ }^{125}$ I-labeled ET-1 (Amersham Japan Co., Tokyo) as a tracer.

RNA isolation. Total RNA from cultured human umbilical vein ECs were extracted by the guanidinium-thiocyanate-phenol-chloroform method (18). In brief, the cells were scraped and homogenized with $2 \mathrm{ml}$ of solution buffer (4 M guanidium thiocyanate, $25 \mathrm{mM}$ sodium citrate, $\mathrm{pH} 7.0,0.5 \%$ sarcosyl, and $0.1 \mathrm{M}$ 2-mercaptoethanol) 
and subsequently transferred to a polypropylene tube. Sequentially, 0.2 $\mathrm{ml}$ of $2 \mathrm{M}$ sodium acetate, $2 \mathrm{ml}$ phenol (water saturated), and $0.4 \mathrm{ml}$ of chloroform-isoamyl alcohol mixture (49:1) were added to the homogenate, with thorough mixing by inversion. The final suspension was shaken vigorously for $10 \mathrm{sec}$ and cooled on ice for $15 \mathrm{~min}$. Samples were centrifuged at $10,000 \mathrm{~g}$ for $20 \mathrm{~min}$ at $4^{\circ} \mathrm{C}$. After centrifugation, RNA in the aqueous phase was transferred to a fresh tube, mixed with 2 $\mathrm{ml}$ of isopropanol, and then placed at $-20^{\circ} \mathrm{C}$ for at least $2 \mathrm{~h}$ to precipitate RNA. Sedimentation at $10,000 \mathrm{~g}$ for $20 \mathrm{~min}$ was again performed and the resulting RNA pellet was resuspended in $75 \%$ ethanol, sedimented, vacuum dried, and used as total RNA.

Northern blot analysis for ET-1 $m R N A$. Total RNA was denatured with $6 \%$ formaldehyde, fractionated by $1 \%$ agarose gel electrophoresis, and transferred to a nylon membrane (Hybond-N; Amersham Japan ). The membranes were prehybridized at $42^{\circ} \mathrm{C}$ for $5 \mathrm{~h}$ in a buffer containing $50 \%$ formamide, $5 \times$ Denhardt's reagent, $10 \%$ Dextran sulfate, $5 \times$ saline EDTA, and $100 \mu \mathrm{g} / \mathrm{ml}$ denatured single strand DNA, and then hybridized with ${ }^{32} \mathrm{P}$-labeled $1.2 \mathrm{~kb}$ EcoRI fragment of human preproendothelin-1 cDNA probes $(20)$ in the same buffer at $42^{\circ} \mathrm{C}$ for $16 \mathrm{~h}$. After washing the filters, the hybridized RNA was visualized by exposure to Hyperfilm-TM (Amersham Japan) at $-70^{\circ} \mathrm{C}$. The membrane was prehybridized, hybridized, and washed as the Northern blot. The membranes were reprobed with a human $\beta$-actin cDNA. The probe was labeled with $\left[\alpha-{ }^{32} \mathrm{P}\right] \mathrm{dCTP}$ by the multiprime DNA labeling system (Amersham Japan). After exposure to film, the probe was stripped by incubation in a buffer containing $5 \mathrm{mM}$ Tris- $\mathrm{HCl}, \mathrm{pH} 8.0,2 \mathrm{mM}$ EDTA, and $0.1 \times$ Denhardt's reagent at $70^{\circ} \mathrm{C}$ for $1 \mathrm{~h}$. The results were quantitated using a laser densitometer (Pharmacia LKB Biotechnology AB, Uppsala, Sweden).

Measurement of cGMP levels. Confluent ECs cultured in 6-well plates were preincubated for $15 \mathrm{~min}$ at $37^{\circ} \mathrm{C}$ in $1.4 \mathrm{ml}$ of incubation buffer having the following composition $(\mathrm{mM}): 137 \mathrm{NaCl}, 2.7 \mathrm{KCl}, 8$ $\mathrm{Na}_{2} \mathrm{HPO}_{4}, 1.5 \mathrm{KH}_{2} \mathrm{PO}_{4}, 0.5 \mathrm{CaCl}_{2}, 0.5 \mathrm{MgCl}_{2}$, 3-isobutyl-1-methylxanthine 1 , and 0.01 indomethacin. The incubation was started by adding $100 \mu \mathrm{l}$ of solution (including heparin, thrombin, LNMMA, or these items in combination) and was stopped by adding $25 \mu \mathrm{l}$ of $\mathrm{HCl}$ ( 1 $\mathrm{N}$ ) after 30-min incubation according to the method previously published (17). $1 \mathrm{~h}$ later, the buffer was then removed and neutralized with $25 \mu \mathrm{l}$ of $\mathrm{NaOH}$ ( $1 \mathrm{~N}$ ), and CGMP was measured by RIA using a cGMP assay kit (Yamasa Shoyu Co. Ltd., Chiba, Japan ).

Nitrite $\left(\mathrm{NO}_{2}\right) /$ nitrate $\left(\mathrm{NO}_{3}\right)$ assay. Cultured cells were assayed for $\mathrm{NO}$ synthesis by measuring the stable end product of $\mathrm{NO}, \mathrm{NO}_{2}$, and $\mathrm{NO}_{3}$, as described by Bartholomew (21) and Granger et al. (22). The cells were cultured in standard cultured flasks $\left(5-7 \times 10^{6}\right.$ cells) and incubated with several agents including heparin, thrombin, LNMMA, or these agents in combination in Dulbecco's PBS (D-PBS) with 70 $\mathrm{mg} /$ liter of L-arginine hydrochloride for $2 \mathrm{~h}$. After incubation, the medium was removed and cells were rinsed three times with PBS, followed by scraping cell layers into cold PBS. Homogenates were obtained by drawing the cell suspension through 25-gauge needles three times on ice. Samples were first incubated with Escherichia coli nitrate reductase to convert the $\mathrm{NO}_{3}$ in the samples to $\mathrm{NO}_{2}(23)$ for $90 \mathrm{~min}$ at $37^{\circ} \mathrm{C}$, as reported previously (22). After incubation, the total $\mathrm{NO}_{2}$ in the samples were measured using Greiss reagents as reported by Green et al. (24). Absorbance was measured at $543 \mathrm{~nm}$ by spectrophotometer. Known concentration of $\mathrm{NaNO}_{2}$ and $\mathrm{NaNO}_{3}$ were used as standards in each assay.

Calculation and statistical analysis. The statistical significance of the results was evaluated by ANOVA and $P$ values were determined by the Student's $t$ test.

\section{Results}

Effects of heparin on immunoreactive ET-1 release from cultured human ECs. We assayed the release of ET-1 by measuring immunoreactive ET-1 level in the medium of human ECs

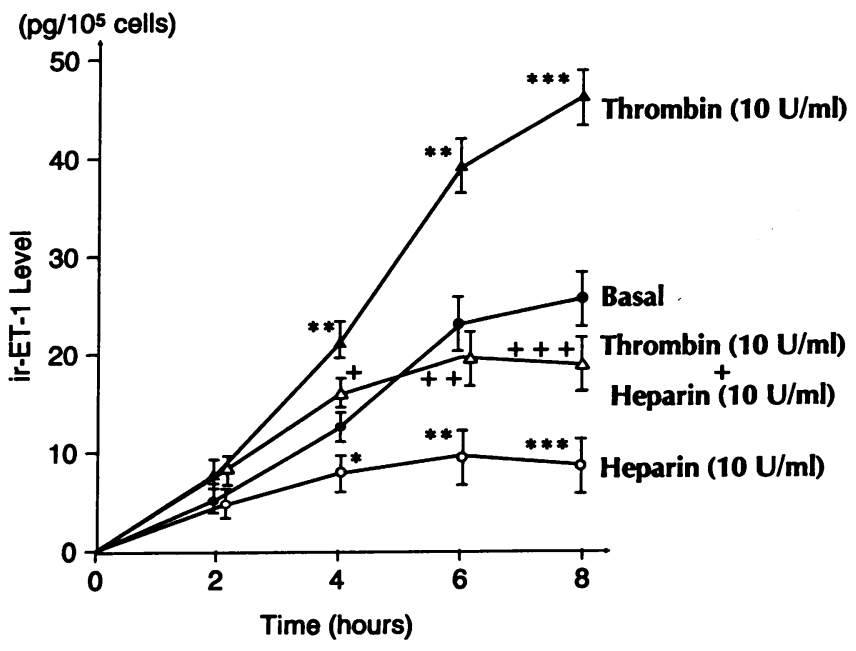

Figure 1. Time-dependent accumulation of immunoreactive (ir) ET1 in human umbilical vein EC cultured medium. The cultured ECs of human umbilical vein were incubated with or without heparin ( 10 $\mathrm{U} / \mathrm{ml})$ and thrombin $(10 \mathrm{U} / \mathrm{ml})$. The ET- 1 content in the medium was measured at $2,4,6$, and $8 \mathrm{~h}$. Data are means \pm SEM of five experiments. ${ }^{*} P<0.05,{ }^{* *} P<0.01,{ }^{* *} P<0.001$ ( $t$ test $)$, compared with simultaneous basal values. $+P<0.05,++P<0.01,+++P$ $<0.001$, compared with the values just in the presence of thrombin $(10 \mathrm{U} / \mathrm{ml})$.

culture in the presence or absence of heparin (Fig. 1). Immunoreactive ET-1 was released from cultured human ECs in a timedependent manner. Thrombin $(10 \mathrm{U} / \mathrm{ml})$ enhanced ET-1 release. Addition of heparin at a dose of $10 \mathrm{U} / \mathrm{ml}$ significantly decreased both basal and thrombin-stimulated ET-1 levels in the medium. In our preliminary study heparin did not interfere with our assay of ET-1.

Effect of heparin on ET-1 mRNA expression. As shown in Fig. 2, heparin (1-50 U/ml) suppressed both basal and thrombin $(10 \mathrm{U} / \mathrm{ml})$-stimulated ET-1 mRNA expression in cultured human ECs in a dose-dependent fashion. We compared ET-1 mRNA expression between 1- and 4-h incubation periods (Fig. 3). ET-1 mRNA increased more in 4-h incubation than that in $1-\mathrm{h}$ incubation. However, heparin $(10 \mathrm{U} / \mathrm{ml})$ suppressed ET-1 mRNA expression in a time-dependent manner.

To know whether heparin inhibits ET-1 mRNA expression at the transcriptional level, we have measured vehicle- or thrombin $(10 \mathrm{U} / \mathrm{ml})$-stimulated ET-1 mRNA expression in cultured ECs by 1-h incubation with a transcriptional inhibitor, actinomycin D (AD), at $5 \mu \mathrm{g} / \mathrm{ml}$ (Table I). Addition of $\mathrm{AD}$ at time 0 resulted in almost complete inhibition of the transcription of ET-1 mRNA. When AD was added at 30 min, ET-1 mRNA expression measured after another $30 \mathrm{~min}$ (in a total 1-h incubation) decreased compared to the control level, indicating that AD arrests new RNA synthesis after $30 \mathrm{~min}$ in cells incubated with thrombin or vehicle. When heparin (20 $\mathrm{U} / \mathrm{ml}$ ) was added at time $30 \mathrm{~min}$, ET-1 mRNA expression measured after another $30 \mathrm{~min}$ decreased, compared with the control value. However, when heparin was added with $\mathrm{AD}$ at time $30 \mathrm{~min}$, no further inhibition of ET-1 mRNA expression measured after another $30 \mathrm{~min}$ (in total 1-h incubation) was observed compared to those treated with just AD at time 30 min in cells incubated with thrombin or vehicle. These results 


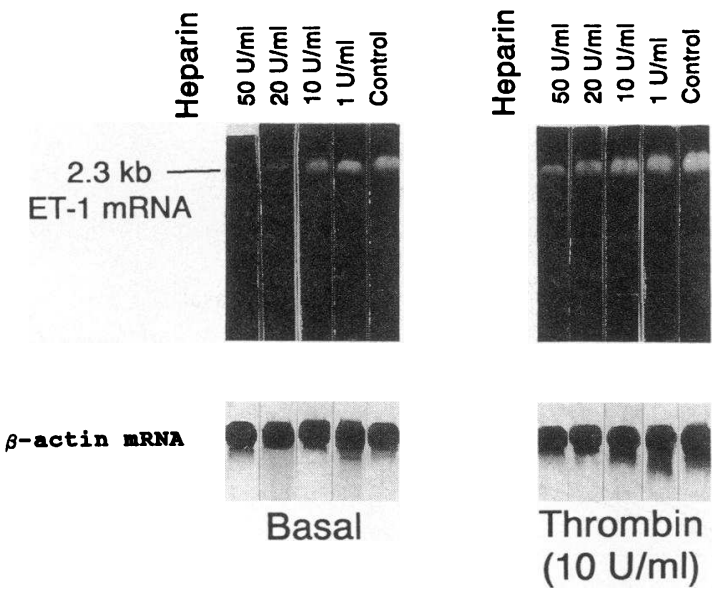

Figure 2. Effect of heparin on basal and thrombin $(10 \mathrm{U} / \mathrm{ml})-$ stimulated ET-1 mRNA expression. The growth-arrested cultured human ECs were exposed to serum-free medium-199 with various concentrations of heparin $(1-50 \mathrm{U} / \mathrm{ml})$ in the presence or absence of thrombin $(10 \mathrm{U} / \mathrm{ml})$ for $2 \mathrm{~h}$. Total cellular RNA was isolated and ET-1 mRNA expression was determined by Northern analysis. The mRNA optical density for each lane was standardized to that of the constituently released human $\beta$-actin gene expression as follows (left to right ): $0.04,0.06,0.14,0.19,0.20,0.14,0.16,0.20,0.22$, and 0.28 , each, and the calculated ratio of ET-1 signal to basal control value is $0.2,0.3,0.7,0.9$, and 1.0 in basal, and 0.7, 0.8, 1.0, 1.1, and 1.4 in the presence of thrombin $(10 \mathrm{U} / \mathrm{ml})$, respectively, from left lane to right.

suggest that heparin regulates the transcription rates of ET-1 mRNA expression in cells incubated with thrombin or vehicle.

Effect of heparin on cGMP production in the presence or absence of LNMMA. As shown in Fig. 4, heparin enhanced basal and thrombin-stimulated cGMP production by cultured human ECs without serum in a dose-dependent manner. cGMP production was more marked in the presence of thrombin $(10 \mathrm{U} / \mathrm{ml})$ than in its absence. On the other hand, in the presence of EDNO inhibitor LNMMA $\left(10^{-5} \mathrm{M}\right)$, heparin had no effect on either basal or thrombin-stimulated cGMP level
Table I. Effects of AD and Heparin on ET-1 mRNA Expression Stimulated by Vehicle and Thrombin in Cultured Human Umbilical Vein ECs

\begin{tabular}{lcc}
\hline & \multicolumn{2}{c}{$\begin{array}{c}\text { ET-1 mRNA level } \\
\text { (Absorbance) }\end{array}$} \\
\cline { 2 - 3 } & Vehicle & Thrombin \\
\hline & & $10 \mathrm{U} / \mathrm{ml}$ \\
Control (60 min) & $0.16 \pm 0.046$ & $0.50 \pm 0.097$ \\
Control (30 min) & $0.08 \pm 0.020$ & $0.22 \pm 0.060$ \\
AD at time 0 & $0.01 \pm 0.005$ & $0.01 \pm 0.006$ \\
AD at time 30 min & $0.07 \pm 0.020$ & $0.20 \pm 0.083$ \\
Heparin at time 0 & $0.09 \pm 0.036$ & $0.14 \pm 0.056$ \\
Heparin at time 30 min & $0.12 \pm 0.041$ & $0.27 \pm 0.089$ \\
Heparin + AD at time 30 min & $0.07 \pm 0.017$ & $0.20 \pm 0.066$ \\
Heparin at time 0+ & & \\
AD at time 30 min & $0.05 \pm 0.020$ & $0.07 \pm 0.026$
\end{tabular}

Growth-arrested human umbilical vein ECs were treated with or without heparin $(20 \mathrm{U} / \mathrm{ml})$ and $\mathrm{AD}(5 \mu \mathrm{g} / \mathrm{ml})$ at various periods and ET-1 mRNA expression was detected after total 1-h incubation (except control $30 \mathrm{~min})$. Vehicle or thrombin $(10 \mathrm{U} / \mathrm{ml})$ was added at time 0 . ET-1 mRNA level was quantitated by laser densitometer (Pharmacia LKB Biotechnology AB, Uppsala, Sweden). Data are means of three experiments \pm SD.

(Table II). However, basal level of cGMP was not affected by LNMMA, similarly observed by other investigators (15).

Effect of heparin on ET-1 production in the presence of $L N M M A$. Like cGMP, heparin showed no effect on either basal or thrombin-stimulated ET-1 peptide release into the medium in the presence of LNMMA $\left(10^{-5} \mathrm{M}\right)$, although heparin suppressed both basal and thrombin-stimulated ET-1 release without LNMMA (Table III). Similarly, the suppressive effect of heparin on basal and thrombin-stimulated ET-1 mRNA expression was not observed in the presence of LNMMA at $10^{-5}$ M (Fig. 5).

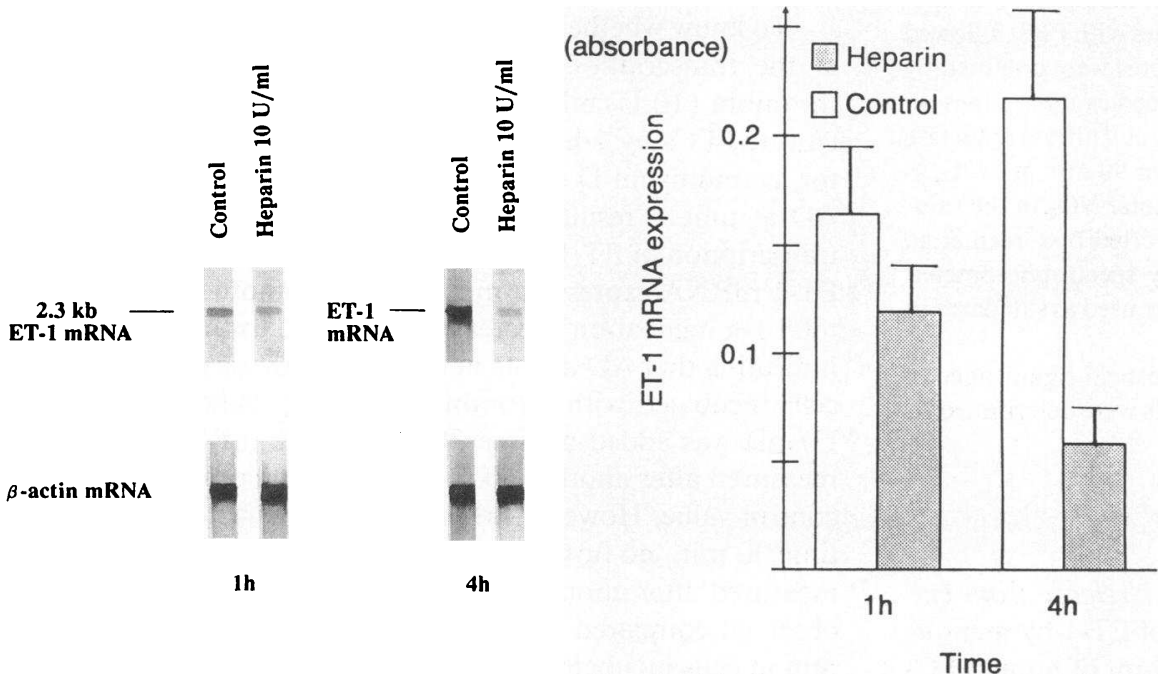

Figure 3. The ET-1 mRNA expression in cultured human ECs in 1- and 4-h incubation with or without heparin $(10 \mathrm{U} / \mathrm{ml})$ were presented (left panel). The densitometric measurements of means \pm SD of three experiments are shown (right panel). 


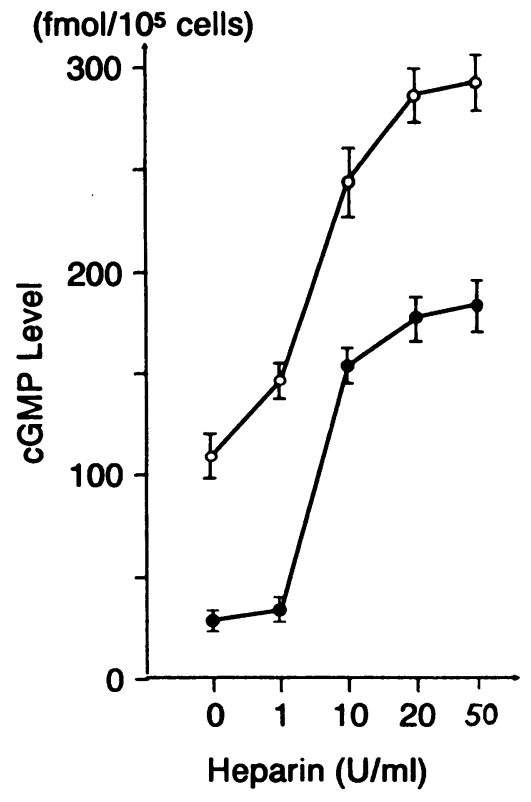

Effect of heparin on the production of $\mathrm{NO}_{2} / \mathrm{NO}_{3}$ in cultured human ECs. As shown in Table IV, heparin induced the production of $\mathrm{NO}_{2} / \mathrm{NO}_{3}$ in cultured human $\mathrm{ECs}$ in a dose-dependent manner. Heparin ( $10 \mathrm{U} / \mathrm{ml}$ ) also enhanced thrombin ( 10 $\mathrm{U} / \mathrm{ml}$ )-induced $\mathrm{NO}_{2} / \mathrm{NO}_{3}$ production. In the presence of LNMMA $\left(10^{-5} \mathrm{M}\right)$, heparin, thrombin, and a combination of both did not affect the production of $\mathrm{NO}_{2} / \mathrm{NO}_{3}$.

\section{Discussion}

Heparin is a widely used anticoagulant drug. Besides, heparin treatment has shown to cause blood pressure reduction in hypertensive humans $(1)$ and rats $(3-5,16)$. Thrombin is a potent agonist of ET-1 production by cultured human ECs. We have confirmed that thrombin stimulates ET-1 production, and have presented data showing that heparin strongly suppresses both basal and thrombin-stimulated ET-1 mRNA expression and ET-1 peptide release. It has been reported that

Table II. Effect of LNMMA on the Production of cGMP in Cultured Human ECs

\begin{tabular}{lcc}
\hline & Control & LNMMA \\
\hline & & $10^{-5} M$ \\
Basal & $29.4 \pm 6.5$ & $31.4 \pm 8.8$ \\
Heparin $(10 \mathrm{U} / \mathrm{ml})$ & $154.2 \pm 15.9^{*}$ & $32.0 \pm 8.3^{\ddagger}$ \\
Thrombin $(10 \mathrm{U} / \mathrm{ml})$ & $110.6 \pm 17.1^{*}$ & $28.4 \pm 11.8^{\ddagger}$ \\
$\left.\begin{array}{c}\text { Thrombin }(10 \mathrm{U} / \mathrm{ml}) \\
\quad+ \\
\text { Heparin }(10 \mathrm{U} / \mathrm{ml})\end{array}\right\}$ & $245.0 \pm 32.0^{*}$ & $35.0 \pm 11.9^{\ddagger}$ \\
& &
\end{tabular}

Cultured human ECs were incubated with the above agents for 30 min and cGMP level in EC extract was measured by radioimmunoassay. Data are means $\pm \mathrm{SD}$ of five experiments ( $\mathrm{fmol} / 10^{5}$ cells). ${ }^{*} P$ $<0.001$ ( $t$ test) compared to basal values. ${ }^{\ddagger} P<0.001$ ( $t$ test) compared to each control (without LNMMA) value.

Table III. Effect of LNMMA on the ET-1 Peptide Release in Cultured Human ECs

\begin{tabular}{|c|c|c|}
\hline & Control & LNMMA \\
\hline & & $10^{-5} \mathrm{M}$ \\
\hline Basal & $12.4 \pm 2.6$ & $13.0 \pm 4.4$ \\
\hline Heparin $(10 \mathrm{U} / \mathrm{ml})$ & $7.8 \pm 3.3^{*}$ & $14.0 \pm 5.1^{11}$ \\
\hline Thrombin $(10 \mathrm{U} / \mathrm{ml})$ & $21.0 \pm 4.4^{\ddagger}$ & $31.8 \pm 5.7^{5,1}$ \\
\hline Thrombin $(10 \mathrm{U} / \mathrm{ml}))$ & & \\
\hline $\left.\begin{array}{c}+ \\
\text { Heparin }(10 \mathrm{U} / \mathrm{ml})\end{array}\right\}$ & $15.8 \pm 3.4$ & $32.0 \pm 7.3^{8.1}$ \\
\hline
\end{tabular}

ECs were incubated with the above agents for $4 \mathrm{~h}$ and immunoreactive ET-1 level in cultured medium was determined by RIA. Data are means $\pm \mathrm{SD}$ of five experiments $\left(\mathrm{pg} / 10^{5}\right.$ cells). ${ }^{*} P<0.05 ;{ }^{\ddagger} P$ $<0.01 ;{ }^{\S} P<0.001$ ( $t$ test) compared to respective basal values. " $P$ $<0.05 ; \quad ' P<0.01$ ( $t$ test) compared to each control (without LNMMA) value.

ECs do not contain a storage pool of ET-1; secretion of EC ET-1 is regulated primarily at the level of transcription (25). The ET-1 production is regulated by phosphoinositide turnover (25). Heparin selectively inhibits a protein kinase C-dependent mitogenesis, changes in cellular morphology and proto-oncogene induction (26). The ET-1 mRNA expression in cultured human ECs was found to be suppressed by heparin, corresponding to a decrease in ET-1 peptide level in the medium. These findings, together with those of AD experiments, indicate that heparin inhibits ET-1 production, probably at the transcriptional level. However, the effect of heparin on transla-

\section{$2.3 \mathrm{~kb}$ ET-1 mRNA \\ $\beta$-actin mRNA}

$$
\text { Basal }
$$

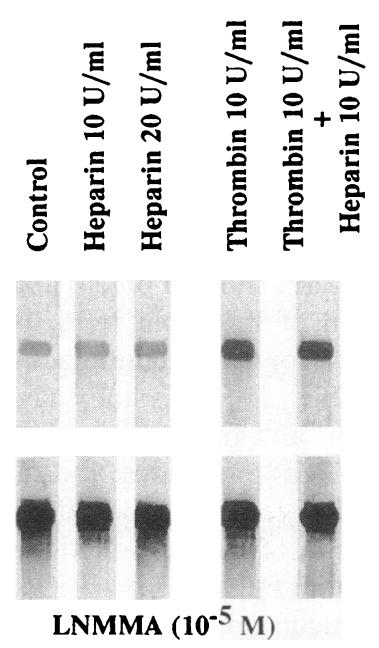

Figure 5. Effect of $\mathrm{N}^{\mathrm{G}}$-monomethyl L-arginine (LNMMA) on the expression of ET-1 mRNA with or without heparin and thrombin in cultured human ECs. ECs were incubated with LNMMA $\left(10^{-5} \mathrm{M}\right)$ in the presence of heparin $(10$ or $20 \mathrm{U} / \mathrm{ml})$, thrombin $(10 \mathrm{U} / \mathrm{ml})$, or of a combination of heparin and thrombin for $2 \mathrm{~h}$. ET- 1 mRNA expression was estimated by Northern analysis. The mRNA optical density for each lane was standardized to that of the constituently released human $\beta$-actin gene expression as follows (left to right): 0.2 , $0.21,0.22,0.21,0.41$, and 0.40 , each, and the calculated ratio of ET-1 signal to control was $1.0,1.1,1.1,1.1,2.1$, and 2.0 , respectively. 
Table IV. Effect of Heparin on the Production of Nitrite and Nitrate $\left(\mathrm{NO}_{2} / \mathrm{NO}_{3}\right)$ in Cultured Human ECs

\begin{tabular}{llc}
\hline & Control & LNMMA \\
\hline & & $10^{-5} M$ \\
Basal & $0.60 \pm 0.15$ & $0.44 \pm 0.17$ \\
Heparin, $5 \mathrm{U} / \mathrm{ml}$ & $1.06 \pm 0.24^{\ddagger}$ & $0.44 \pm 0.16^{*}$ \\
\multicolumn{1}{c}{, $10 \mathrm{U} / \mathrm{ml}$} & $1.99 \pm 0.57^{\S}$ & $0.48 \pm 0.16^{*}$ \\
, $20 \mathrm{U} / \mathrm{ml}$ & $2.29 \pm 0.63^{\S}$ & $0.53 \pm 0.17^{*}$ \\
Thrombin, $10 \mathrm{U} / \mathrm{ml}$ & $1.79 \pm 0.63^{\S}$ & $0.43 \pm 0.20^{*}$ \\
Thrombin, $10 \mathrm{U} / \mathrm{ml}$ \\
$\left.\begin{array}{l} \pm \\
\text { Heparin, } 10 \mathrm{U} / \mathrm{ml}\end{array}\right\}$ & $4.56 \pm 0.82^{\S}$ & $0.57 \pm 0.20^{*}$ \\
& & \\
\hline
\end{tabular}

ECs were incubated with the above agents for $2 \mathrm{~h}$ and $\mathrm{NO}_{2} / \mathrm{NO}_{3}$ levels were measured as described in Methods. Data are means \pm SD of five samples of $\mathrm{NO}_{2} / \mathrm{NO}_{3}$ level (pmol/105 cells per $2 \mathrm{~h}$ ). ${ }^{*} P<0.001$ ( $t$ test) compared to each control value. ${ }^{\ddagger} P<0.01,{ }^{\S} P<0.001$ ( $t$ test) compared to basal values.

tion and/or on conversion of big-ET-1 ( 38 amino acids) to ET-1 ( 21 amino acids) remains to be clarified.

Thrombin stimulates not only the production of the endothelin group, but also the production of vasodilator EDNO in a variety of blood vessels $(27,28)$. EDNO production can be inhibited stereospecifically by LNMMA, which is a false substrate for the enzyme synthesizing nitric oxide $(29,30)$. Nitric oxide activates soluble guanylate cyclase and in turn increases cGMP level in ECs and VSMCs (31-33). We have shown that both thrombin and heparin stimulate NO formation measured by $\mathrm{NO}_{2} / \mathrm{NO}_{3}$ levels and cGMP production, and a combination of both markedly enhances the NO formation and the cGMP production. However, these heparins' stimulatory effect on NO formation and cGMP production were abolished in the presence of LNMMA, suggesting that heparin stimulates cGMP through EDNO-mediated pathway. Furthermore, in the presence of LNMMA, heparin did not affect either basal or thrombin-stimulated ET-1 mRNA expression and ET-1 peptide release. Therefore, these results suggest that heparin suppresses ET-1 production through an EDNO-cGMP mediated pathway. Heparin shows a potent anticoagulant action through inactivation of thrombin by activating antithrombin III in a serum (34) or by direct interaction with anion-binding exosite of thrombin (35). This study has been done under a serum-free condition, and furthermore, heparin enhanced thrombin-induced cGMP production and did not suppress ET-1 production in the presence of LNMMA. These findings indicate that suppression of ET-1 production is not due to the inactivation of thrombin by heparin.

In conclusion, our study provides a novel finding that heparin stimulates CGMP production in cultured human ECs, and subsequently suppresses the ET-1 production, probably at the transcriptional level through an EDNO-mediated pathway. Furthermore, heparin also enhances thrombin-stimulated cGMP production in cultured ECs without serum, and suppresses thrombin-induced ET-1 production through the activation of an EDNO-mediated pathway. Taken together, it may be prudent to state that heparin regulates vascular tone through a combination of enhancement of EDNO and suppression of ET-1 production in human ECs.

\section{References}

1. Abbott, E. C., A. G. Gornall, D. J. Sutherland, J. C. Laidlaw, and M. Stiefel. 1966. The influence of a heparin-like compound on hypertension, electrolytes and aldosterone in man. Can. Med. Assoc. J. 94:1155-64.

2. Sealey, J. E., J. N. Gerten, J. G. G. Ledingham, and J. H. Laragh. 1967. Inhibition of renin by heparin. J. Clin. Endocrinol. \& Metab. 27:699-705.

3. Susic, D., A. K. Mandal, and D. Kentera. 1982. Heparin lowers the blood pressure in hypertensive rats. Hypertension (Dallas). 4:681-685.

4. Wilson, S. K., K. Solez, J. Boitnott, and R. H. Heptinstall. 1981. The effect of heparin treatment on hypertension and vascular lesions in stroke-prone spontaneously hypertensive rats. Am. J. Physiol. 102:62-71.

5. Purkerson, M. L., P. E. Hoffsten, and S. Klahr. 1976. Pathogenesis of the glomerulopathy associated with renal infarction in rats. Kidney Int. 9:407-417.

6. Susic, D., A. K. Mandal, and D. Kentera. 1984. Hemodynamic effects of chronic alteration in hematocrit in spontaneously hypertensive rats. Hypertension (Dallas). 6:262-266.

7. Yanagisawa, M., H. Kurihara, S. Kimura, Y. Tomobe, M. Kobayashi, Y. Mitsui, Y. Yazaki, K. Goto, and T. Masaki. 1988. A novel potent vasoconstrictor peptide produced by vascular endothelial cells. Nature (Lond.). 332:411-415.

8. Komuro, I., H. Kurihara, T. Sugiyama, F. Takaku, and Y. Yazaki. Endothelin stimulates c-fos and c-myc expression and proliferation of vascular smooth muscle cells. FEBS (Fed. Eur. Biochem. Soc.) Lett. 238:249-252.

9. Miyauchi, T., M. Yanagisawa, T. Tomizawa, Y. Sugishita, M. Fijino, R. Ajisaka, K. Goto, and T. Masaki. 1989. Increased plasma concentration of endothelin-1 and big-endothelin-1 in acute myocardial infarction. Lancet. ii:53-54.

10. Firth, J. D., P. J. Ratcliffe, A. E. G. Raine, and J. G. G. Ledingham. 1988. Endothelin: an important factor in acute renal failure? Lancet. ii:1179-1181.

11. Kohno, M., K. Yasunari, K. Murakawa, K. Yokokawa, T. Horio, T. Fukui, and T. Takeda. 1990. Plasma immunoreactive endothelin in essential hypertension. Am. J. Med. 88:614-618.

12. Yokokawa, K., H. Tahara, M. Kohno, K. Murakawa, K. Yasunari, K. Nakagawa, T. Hamada, S. Otani, M. Yanagisawa, and T. Takeda. 1991. Hypertension associated with endothelin-secreting malignant hemangioendothelioma. Ann. Intern. Med. 114:213-215.

13. Vallance, P., J. Collier, and S. Moncada. 1989. Effects of endotheliumderived nitric oxide on peripheral arteriolar tone in man. Lancet. ii:997-1000.

14. Garg, U. C., and A. Hassid. 1989. Nitríc oxide-generating vasodilators and 8-bromo-cyclic guanosine monophosphate inhibit mitogenesis and proliferation of cultured rat vascular smooth muscle cells. J. Clin. Invest. 83:1774-1777.

15. Boulanger, C., and T. F. Luscher. 1990. Release of endothelin from the porcine aorta. J. Clin. Invest. 85:587-590.

16. Yokokawa, K., A. K. Mandal, M. Kohno, T. Horio, K. Murakawa, K. Yasunari, and T. Takeda. 1992. Heparin suppresses endothelin-1 action and production in spontaneously hypertensive rats. Am. J. Physiol. 263:R1035R1041.

17. Yokokawa, K., M. Kohno, K. Yasunari, K. Murakawa, and T. Takeda. 1991. Endothelin-3 regulates endothelin-1 production in cultured human endothelial cells. Hypertension (Dallas). 18:304-315.

18. Chomczynski, P., and N. Sacchi. 1987. Single-step method of RNA isolation by acid guanidinium thiocyanate-phenol-chloroform extraction. Anal. Biochem. 162:156-159.

19. Yokokawa, K., H. Tahara, M. Kohno, K. Murakawa, K. Yasunari, K. Nakagawa, T. Hamada, S. Otani, M. Yanagisawa, and T. Takeda. 1991. Endothelin-secreting tumor. J. Cardiovasc. Pharmacol. 17(Suppl. 7):S398-S401.

20. Inoue, A., M. Yanagisawa, Y. Takuwa, Y. Mitsui, M. Kobayashi, and T. Masaki. 1989. The human preproendothelin-1 gene. J. Biol. Chem. 264:1495414959.

21. Bartholomew, B. 1984. A rapid method for the assay of nitrate in urine using the nitrate reductase enzyme of Escherichia coli. Food. Chem. Toxicol. 22:541-543.

22. Granger, D. L., J. B. Hibbs, Jr., J. R. Perfect, and D. T. Durack. 1990. Metabolic fate of L-arginine in relation to microbiostatic capability of murine macrophages. J. Clin. Invest. 85:264-273.

23. Shultz, P. J., and L. Raij. 1992. Endogenously synthesized nitric oxide prevents endotoxin-induced glomerular thrombosis. J. Clin. Invest. 90:17181725 .

24. Green, L. C., D. A. Wagner, J. Glogowski, P. L. Skipper, J. S. Wishnok, and S. R. Tannenbaum. 1982. Analysis of nitrate, nitrite, and $\left[{ }^{15} \mathrm{~N}\right]$ nitrate in biological fluids. Anal. Biochem. 126:131-138.

25. Yanagisawa, M., A. Inoue, Y. Takuwa, Y. Mitsui, M. Kobayashi, and T. Masaki. 1989. The human preproendothelin-1 gene: possible regulation by endothelial phosphoinositide turnover signaling. J. Cardiovasc. Pharmacol. 13(Suppl. 5):S13-S17.

26. Wright, T. C., L. A. Pukac, J. J. Castellot, M. J. Karnovsky, R. A. Levine, G. H. Kim-Park, and J. Campisi. 1989. Heparin suppresses the induction of c-fos and c-myc in murine fibroblasts by selective inhibition of a protein kinase C-dependent pathway. Proc. Natl. Acad. Sci. USA. 86:3199-3203. 
27. De Mey, J. G., M. Claeys, and P. M. Vanhoutte. 1982. Endothelium-dependent inhibitory effects of acetylcholine, adenosine diphosphate, thrombin and arachidonic acid in the canine femoral artery. J. Pharmacol. Exp. Ther. 222:166173.

28. Rapoport, R. M., M. B. Draznin, and F. Murad. 1984. Mechanisms of the adenosine triphosphate-, thrombin- and trypsin-induced relaxation of rat thoracic aorta. Circ. Res. 55:468-479.

29. Rees, D. D., R. M. J. Palmer, H. F. Hodoson, and S. Moncada. 1989. A specific inhibitor of nitric oxide formation from $\mathrm{L}$-arginine attenuates endothelium-dependent relaxations. Br. J. Pharmacol. 96:418-424.

30. Sakuma, I., D. J. Stuehr, S. S. Gross, C. Nathan, and R. Levi. 1988. Identification of arginine as a precursor of endothelium-derived relaxing factor. Proc. Natl. Acad. Sci. USA. 85:8664-8667.

31. Ignarro, L. J., R. G. Harbison, K. S. Wood, and P. J. Kadwitz. 1986. Activation of purified soluble guanylate cyclase by endothelium derived relaxing factor from intrapulmonary artery and vein: stimulation by acetylcholine, bradykinin, and arachidonic acid. J. Pharmacol. Exp. Ther. 237:893-900.

32. Arnold, W. P., C. K. Mittal, S. Katsuki, and F. Murad. 1977. Nitric oxide activates soluble guanylate cyclase and increases guanosine 3', 5'-cyclic monophosphate in various tissue preparations. Proc. Natl. Acad. Sci. USA. 74:32033207.

33. Boulanger, C., V. B. Schini, S. Moncada, and P. M. Vanhoutte. 1990. Stimulation of cyclic GMP production in cultured endothelial cells of the pig by bradykinin, adenosine diphosphate, calcium ionophore A23187 and nitric oxide. Br. J. Pharmacol. 101:152-156.

34. Rosenberg, R. D., and P. S. Damus. 1973. The purification and mechanism of action of human antithrombin-heparin cofactor. J. Biol. Chem. 248:6490-6505.

35. Fenton, J. W., II, J. I. Witting, C. Pouliott, and J. Fareed. 1989. Thrombin anion-binding exosite interactions with heparin and various polyanions. Ann. NY. Acad. Sci. 556:158-165. 